Machado P. P. \& Neufeldt, S. A. (1994). Therapist variables. In A. E. Bergin \& S. L. Garfield (Eds.), Handbook of psychotherapy and behavior E. Bergin \& S. L. Garfield (Eds.), New York: Wiley.

change (4th ed., pp. 229-269). Ne). Are social-cognitive ability and narrative urleson, B. R., \& Rowan, K. E. (1985). Arication, 2, 25-43.

writing skill related? Written Communication, $2,25-43$.

Burleson, B. R., \& Waltman, M. S. (n C. Tardy (Ed.), A handbook for the study Category Questionnaire measure. of human cormm communication processes (pp. 1-35). Norwood, NJ. Ablex. and assessing comm Smaby, M., Maddux, C., Torres-Rivera, E., Urbani, S., et Crews, J., Smith, M., Smitoring and counseling skills: Skills-based versus interal. (2005). Selfess recall training. Journal of Counseling \& Development, 83 . 78-85.

Crockett, W. H. (1965). Cognitive complexity and impression formation. In B. A. York: Academic.

Crockett, W. H. Press, A. N., Delia, J. G., \& Kenney, C. J. (1974). The structural analysis of the organization of written

. Kansas at Lawrence. Duys, D., \& Hedstrom, S. M. (2000). Basic counselor sko, 40, 8-19. lor complexity. Counselor Education and Superulsion and interventions. BosHackney, H. \& Cormier, S. (1994). Counseling strategies and interventio ton: Allyn \& Bacon.

Hollis, J., \& Dodson. T. (1999). Counselor preparation ulty, trends (10th ed.). New York: Taylor \& Francis. New York: Norton.

Kelly, G. (1955). The psychology of personal const unaware of it: How difficulties Kruger, J., \& Dunning, D. (199). Unsk lo in recognizing one's own incompetence lead to inflated

of Personality and Social Psychology, 7 .

Meyer, J. R. (1996). What cognitive differences are mication, 60, 233-253.

egory Questionnaire? Western Journal of Cole for evaluating practicum stu-

Myrick, R. D.. \& Kelly, D. F., Jr. (1971). Counselor Education and Supervision, dents in couns

12. 330-336. 364$)$ Educational measurement and evaluation. New York: Nunnaly, J. C.

McGraw Hill.

O'Keefe, D. J., Shepherd, G. J., \& Streeter, Reliability and comparability of alternaire measures of cognitive complexity. Rel. 33, 333-338.

nate forms. Central States Speech Journal. 33. (1971). Children's description of Scarlett, H. H., Press, A. N.. \& Crockal analysis. Child Development, 42, 439-453. peers: A Wernian developmental analysir. E., \& Zimmick, R. (1999). A study Smaby, M. H.. Maddux, C. D., Tersus a conventional group counseling rainof the effects of a skills-based versus a in Group Work, 24, 152-163.

ing program. The Journal for Speciddux, C.. Smaby, M. H., \& Phan, L. T. Torres-Rivera, E., Wilbur, M. Panstruct validity of the Counselor Skills Per(2002). Factor structure and Form. Counselor Education and Supervision, 41 $268-278$.

Uraddux, C. D., Smaby, M. H., Torres-Rivera, E., \& rbani, S.. Smith, M. R., Maddux, Counse Crews, J. (2002). Supervision, 42, 93-106.

(2000). Improving the use of a group theory and skills integration. counseling scale and related moisel to $39,284-295$

\section{The Emergence Model: An Alternative Pedagogy for Facilitating Self-Reflection and Theoretical Fit in Counseling Students}

\section{Douglas A. Guiffrida}

The author presents a critical review of counselor education literature that has focused on student acquisition of theoretical orientations in self-reflection and theoretical fit among students. Two reflective. awareness-based pedagogical models-radical constructivism ( $\mathrm{E}$ von Glasersfeld, 1984) and transformative learning (J. Mezirow, 1997)are also examined. The author concludes by briefly outlining an alternative pedagogical framework called the "Emergence Model." which may enhance the ability of counselor educators to facilitate self-reflection and theoretical fit among counseling students.

Recently, counselor educators have argued that pedagogical methods used to educate counselors, many of which date back to the early $1920 \mathrm{~s}$, are in need of revision to prepare counselors for the diverse. complex issues they will face in today's schools and agencies (Hayes \& Paisley, 2002; House \& Sears, 2002). One area of counselor training that has received attention, lately, from some counselor educators is the ways in which counselor educators assist students in understanding and developing theoretical orientations (Hanna. Giordana, \& Bemak, 1996; Kottler \& Young, 2002). Hackney, Collins, Kudo, and Collins (2002) have argued that current methods for teaching counseling theories, while preparing students to do well on exams, may not prepare students to use theory in self-reflective ways or assist students in understanding and developing their predisposed notions of helping-two aspects of counseling that they believed to be consistent with the ways in which expert counselors integrate theory into their practice.

Counseling literature supports Hackney et al.'s (2002) assertions regarding the need for counselors to operate from a theory, theories, or set of techniques that fit their predisposed notions of human growth and change (Bernard, 1992; Conway, 1988; Corey, 2001; Hackney \& Cormier, 2001: Hayes \& Paisley, 2002; Kottler, 2002: Poznanski \& McLennan, 1995; Smith, 1999; Spruill \& Benshoff. 2000). Additionally, several counselor educators have described the importance of encouraging students to develop theoretical orientations in self-reflective ways (Hayes \& Paisley, 2002; McAuliffe

Douglas A. Guiffrida, Margaret Warner Graduate School of Education and Human Development, University of Rochester. The author thanks Darrell Leavitt, Karen Mackie, and Kristen Barnes for their assistance in the preparation of this article. Correspondence concerning this article should be addressed to Douglas A. Guiffrida, Margaret Warner Graduate School of Education and Human Development, University of Rochester, Dewey Hall, PO Box 27025, Rochester, NY 14627 (e-mail: Douglas.guiffrida@rochester.edu). 
\& Eriksen, 2000; Neufeldt, 1997), because the ability to self-reflect \& Eriksen. 2000 : Neufeld (1974: Schön 1983. (Argyris \& Schôn, 1974; Schon, 1983. 1995). Moreover, Skovholt and Ronnestad (1992) concluded that critical self-reflection was the most important distinction between counselors who continued to develop and grow professionally versus those who faced professional stagnation and burnout.

However although assisting students in finding a theory that fits with their views of human growth and change and developing a theoretical orientation in a self-reflective manner are widely recognized as important to the development of successful counselors research has indicated that counselor educators have met with only limited success in achieving these objectives with students. For example. studies have shown that many counselors eventually drop the theoretical orientations they selected in their graduate training because they found them to be incompatible with their views of human growth and change (Sammons \& Gravitz, 1990; Skovholt \& Ronnestad, 1992: Stone \& Yan, 1997). Furthermore, in their review of counselor development research. McAuliffe and Eriksen (2000) estimated that up to $50 \%$ of all mental health prac titioners seem to be unreflective in selecting intervention strate gies, which they defined as "adherence to a single technique, and/ or maintenance of the status quo when more inclusive and socially critical interventions are needed" (p. 199).

Given the centrality of critical self-reflection and theoretical fit to the development of successful counselors, it is important to identify pedagogical practices for achieving these objectives. However, there is a dearth of literature exploring strategies that counselor educators can use to enhance student self-reflection and theoretical fit. The purpose of this article is to critically review counselor education pedagogical literature, especially literature focusing on student acquisition of theories, in order to identify the potential of these practices to facilitate critical self-reflection and theoretical fit among students. I also examine two reflective-based models of learning (i.e. radical constructivism and transformative learning) and conclude by briefly outlining an alternative model for counselor educators to consider, called the Emergence Model, for assisting students in developing a personal theory of counseling.

\section{Current Models for Teaching Theories:}

\section{Modernism and Constructivism}

McAuliffe and Eriksen (2000) described two competing paradigms that have significantly influenced counselor education: modern ism and constructivism. Modernists believe in an objective reality in which knowledge exists independent of attempts to observe it (McAuliffe \& Eriksen, 2000). By carefully following scientific principles, modernists posit that universal truths can be discovered and validated. The task of the modernist teacher, therefore, is to identify these universal truths, organize them into useful frameworks, impart this knowledge to students, and evaluate the effec- tiveness of the learning by means of a test or some other instrument (von Glasersfeld, 1984).

The modernist pedagogical format, which Burck, Jacobs, Sauber, Stone, and Thomson (1973) recommended 30 years ago for teaching counseling theories, emphasizes language (i.e., concepts and terminology) as the foundation for learning theories. Modernists believe that instruction of theories should begin by introducing students to each theory's historical origins, fundamental concepts and terminology, view of human growth and change, and intervention strategies through reading and lecture. After students are familiar with the language of the theories. modernists maintain that students should observe each theory in use. often through watching videos and class demonstrations. The modernist approach assumes that experiential learning, which can include case analyses, practice sessions with peers, and small group discussions in which students compare and contrast the different approaches. should occur after students are familiar with the terminology, concepts, and techniques of each theory. In the modernist approach. student learning is evaluated through exams, which assess comprehension of names, terminology, and concepts; essays, which assess writing skills and the ability to critique theory and analyze cases; or role plays, which assess the student's ability to implement or replicate particular approaches.

Granello and Hazler (1998) argued that models of adult development, college student development, and novice to expert models of learning support the modernist approach in which instructors introduce theory using didactic, authoritarian structure that focuses on isolating details and rote memorization. They also asserted that the modernist format is preferable for teaching counseling theories because it reduces student anxiety by providing students with clear learning objectives, practice experiences that gradually become more difficult, and valid measures for evaluating student learning. Cranton (1994) also surmised that students are comfortable with the modernist approach because the process is one with which they are familiar. Additionally, because the modernist approach emphasizes the learning of names, concepts, and terminology, it is ideally suited for preparing students to pass licensure and certification examinations.

Although the modernist approach is useful for conveying information and reducing student anxiety toward learning theories, some counselor educators have argued that the approach prevents students from developing new ways of conceptualizing their work with clients (Nelson \& Neufeldt, 1998) and may not result in consistent counselor conceptual development (Fong, 1998). To understand the limitations of the modernist format of teaching theories, it is helpful to examine critiques of the modernist approach from educators in other fields. For example, science and mathematics educators, such as von Glasersfeld (1984), have raised concern regarding the inability of the modernist pedagogical format to stimulate critical thinking in students. In analyzing the limitations of the 
modernist approach, von Glasersfeld (1984) noted similarities between this sequenced approach (i.e., lecturing, modeling, practicing, and processing) and the sequence used in classic behavioral training. He asserted that behaviorist pedagogy was designed to teach skills and convey knowledge rather than promote awareness and critical selfreflection. He argued further that if replication of a certain theory was the goal, then the modernist approach was appropriate; however, he believed it is an error to assume that the acquisition of skills and concepts will generate understanding and critical reflection.

Modernist pedagogical principles are also apparent in counselor education when one examines the sequence in which theories are taught. Although the Council for Accreditation of Counseling and Related Educational Programs (2001) does not mandate course sequencing, several counselor educators have recommended that theories be taught early in the curriculum so that the theoretical stance that students select can be used as a lens through which they can conceptualize their more advanced courses and early clinical experiences (Granello \& Hazler, 1998; Hayes \& Paisley, 2002 ; Neufeldt, 1999; Spruill \& Benshoff, 2000). Granello and Hazler argued that encouraging students to identify their theoretical orientation(s) early in their training reduces the anxiety that new counselors experience when confronted with ambiguity, which can hinder their capacities to learn and assist their clients.

Teaching students theory before they begin practice, a sequence Schön (1995) has labeled "the normative curriculum" (p. 34), provides students with a guide to begin their practice. Bernard (1992), however, has cautioned that this pedagogical sequence could also place students at risk of theoretical foreclosure by preventing them from discovering their own predisposed notions of human growth and change. Additionally, Schön (1995) argued that teaching students theory before practice hinders the development of self-reflection because it encourages students to force situations into molds that fit their particular theory or theories. According to Schön (1995), novices operating from a particular theory often become selectively inattentive to data that fall outside the theory, or they use junk categories to explain away discrepant data. Moreover, von Glasersfeld (1984) asserted that training that begins by exposing students to existing theories limits students' exploration of new solutions. Because it may be difficult for some counselor educators to conceptualize clinical training that does not begin with instruction of theories, later in this article, I review alternative models that teach theory through observation of one's own practice.

By providing students with clear learning objectives and presenting material and exercises in carefully scaffolded formats, the modernist approach is successful in reducing student anxiety and teaching important historical, contextual, and philosophical assumptions about the various theoretical approaches. However, the limitations of the modernist approach to facilitate self-reflection and theoretical fit are worth exploring in more detail. To better understand the limitations of the modernist approach, it is useful to review constructivist pedagogical assumptions and practices.
Contrary to the objective view of reality held by modernists, constructivists believe that knowledge is subjective and varies depending on the mental construction of each observer (McAuliffe \& Eriksen, 2000). Based on the ideas of Dewey, Piaget, and Vygotsky, constructivists have argued that knowledge cannot be imparted from teacher to student (Bruner, 1966). Rather, these constructivists believe that learning occurs only when the learner is engaged in individual and social activity that promotes discovery (Mezirow, 1997). As a result, this new learning is influenced not only by the current learning experiences but also by students' predisposed notions derived from their prior experiences. Constructivists believe that the teaching of names, dates, terminology, and concepts does more to confuse students than it does to provide a foundation for future learning (von Glasersfeld, 1984). Rather than using language to convey knowledge from the instructor to the students, constructivists have argued that language is a tool that should be used by students to convey their discoveries and understanding of the phenomenon. Furthermore, constructivists believe that it is through the narrative process (i.e., thinking about an experience, critically evaluating it organizing it into logical frameworks, and creating words to express it) that knowledge is actually created (von Glasersfeld, 2000).

The influence of constructivist thinking is apparent in several contemporary theories of counseling (see Greenberg \& PascualLeone, 1995; Mahoney, 1995; White \& Epston, 1990) and supervision (Nelson \& Neufeldt, 1998; Ward \& House, 1998). However. models that describe and advocate for constructivist pedagogy have appeared more scarcely in counselor pedagogical literature. In fact, only Winslade, Monk, and Drewery (1997) have offered a comprehensive model for teaching counseling theories from a constructivis framework. Winslade et al. asserted that to assist students in identifying and understanding their own biases, students must learn to deconstruct social discourse. By implementing activities such as critiquing popular media, Winslade et al. argued that students become sensitive to the ways in which language characterizes social contexts. The authors also teach students the process of cultural colonization by exposing them to other native cultures. After students become familiar with positioning and how to deconstruct discourse, they begin to critique counseling theories from a cultural perspective to identify the cultural biases inherent in each theory. Other constructivist activities recommended by Winslade et al include having students conduct case analyses from a cultural perspective, construct personal narratives in which they reflect on how discourses have shaped them, and participate in plays and small group discussions in which they critically evaluate their actions. Students conclude their training by writing essays in which they reflect on their growth.

The constructivist techniques offered by Winslade et al. (1997). although designed to occur throughout students' training programs, provide a useful foundation for incorporating constructivist pedagogy into the counseling theories course. Although activities such 
as small group discussions, case analyses, role plays, and reflective journaling are also apparent in modernist classrooms, Winslade et al. have adapted these techniques to encourage students to identify and understand the origins of their biases and cultural assumptions. Additionally, these activities teach students to critically evaluate and reflect continually on the various theoretical orientations as they develop their own styles of counseling.

However, Winslade et al. (1997) admitted that their pedagogical framework was designed to teach counselors to become narrative therapists rather than allowing students to identify a theory that fits with their predisposed notions of human growth and change. In addition, although most constructivist counselor educators agree that stimulating dissonance is critical to facilitating reflection (House \& Sears, 2002; Lovell \& McAuliffe, 1997; Nelson \& Neufeldt, 1998; Ward \& House, 1998), the experiential learning methods that Winslade et al. used to stimulate dissonance before students began practice occurred primarily through reading, small group activities, and artificial counseling experiences. Although stimulating reflection through social conversations and dialogue is an important aspect of constructivist pedagogy (Sexton \& Griffin, 1997) Duckworth (1986) argued that the most meaningful reflection occurs when instructors challenge students using authentic, realworld experiences. Similarly, von Glasersfeld (2000) asserted that current pedagogical methods, even those that encourage open discussion, critical analyses, and experiential learning, fail to produce reflective practitioners because they do not challenge learners in real-world contexts.

Argyris and Schön (1974) observed that when confronted with real-world problems, beginning practitioners who have articulated an espoused theory from which to ground their practice often forget or disregard their espoused theories and begin acting on instincts. Recognizing this phenomenon among counselors in their first practicum, Neufeldt (1999) developed a model that assists supervisors in helping students match their espoused theories to what they actually do with clients. However, the fact that students' espoused theories. or the theories they select at the end of their introduction to counseling theories courses, often do not match what they actually do in their initial practice indicates that classroom learning, even when it is experientially based, does not provide sufficient experiences for facilitating the emergence of students' critical selfreflection and theoretical predispositions. To develop a new pedagogy for teaching theories, it is useful to examine pedagogies that emphasize the development of self-reflection through experience.

\section{Self-Reflection Through Practice:}

Radical Constructivism and Transformative Learning

Originally intended for teaching children mathematics and science, von Glasersfeld's (1984) radical constructivism is one example of a pedagogy designed to promote self-reflection and theoretical fit among students through practice. In noting the limi- tations of the modernist approach to stimulate critical thinking among mathematics and science students, von Glasersfeld (1984) argued that true knowing is not just the search for "an iconic representation of ontological reality, but, instead, is a search for fitting ways of behaving and thinking" (p. 35). Unlike other constructivist approaches, which begin by teaching students to critique existing theories and discourses, von Glasersfeld (2000) suggested that mathematics and science teachers begin instruction by introducing students to theories through the "teaching experiment." In this experiential model, students are introduced to mathematical and scientific concepts by attempting to solve the problem before being given the solution. This, the author believed, forced students to rely only on the conceptual operations they have assembled from prior experiences. The teacher's role in the teaching experiment is not to teach students how to solve the problem. but rather to actively attempt to understand students' ways of knowing. Once the instructor understands students' logic, the task is to move the students forward by introducing obstacles and radictions their conceptual structures. Von Glasers and force them to modify this experiential model mat this experiential model not only facilitated the emergence of students' internal knowledge, but it also allowed students to actually create new solutions.

A second pedagogy that is designed to expose students' predispositions and to promote critical self-reflection is Mezirow's (1997) Transformative Model of Learning. Originally developed to serve adult learners in higher education, the model's utility has led to its success in other educational realms (Cranton, 1994). Similar to radical constructivists, transformative educators believe that subject-oriented learning, or learning that focuses on the acquisition of content, fails to empower or engage adult learners because it does not value their frames of references, which are the "structures of assumptions through which we und ences" (Mezirow, 1997, p. 5). Transformative educators believe that adult learners have a strong tendency to accept ideas that fit their frames of reference and to reject those that do not (Cranton fit their frames of reference and to reject those that do not (Cranton, 1994). Therefore, the goal of transformative education is to help adult learners become aware of their internal frames of reference and then guide them "toward a frame of reference that is more inclusive, discriminating, self-reflective, and integrative of experience" (Mezirow, 1997, p. 5).

Although mainstream Western educators do not generally view self-awareness as the central aspect of education, Miller (2001) pointed out that self-awareness has long been a component in several realms of spiritual education that he categorized as transformative, including the pedagogical beliefs of philosophers Jiddu Krishnamurti and Joseph Campbell. In his critique of Western education, Krishnamurti (1953) stated, "Understanding comes only through self-knowledge, which is awareness of one's total psychological process. Thus education, in awareness of one's total psycho- 
of oneself, for it is within each one of us that the whole existence is gathered" (p. 17). Like von Glasersfeld (1984), Krishnamurti believed that forcing students to begin their learning by embracing existing theories was "a convenient escape" (p. 26) for teachers who were unwilling to devote energy toward understanding students as they were. Furthermore, Krishnamurti argued that beginning training by introducing students to theories encouraged them to conform rather than create, which he believed increased student anxiety by creating "a constant conflict between what he [or she] is and what he [or she] should be" (p. 26).

Rather than beginning the process of learning by focusing on facts, concepts, and skills, transformative learning, which is based on the centrality of awareness, begins by teaching students to see themselves as they are (Miller, 2001). According to Campbell (2001) this process begins when students are encouraged to follow their own, unique paths, "which have never been seen and which can be brought into being by no one else" (p. 89). To illustrate this concept, Campbell (2001) pointed out that knights in search of the Holy Grail were not allowed to begin their journeys by entering the for est through the same path. Instead. Campbell noted, "each should enter the forest where he found it darkest, and where no other path existed" (p. 88). Campbell believed that by following one's own path, preexisting notions emerged, thus allowing the person to not only identify these ingrained ways of being, but to begin the process of self-understanding.

Educators who place self-awareness at the forefront do not evaluate students on what was good or bad about their performance but, instead, actively encourage students to make nonjudgmenta observations to identify and understand their own self-projected values and impositions (Miller, 2001). This pedagogy does not assume the essentialist notion that all answers are found from within rather, it assumes that self-awareness is merely the starting point from which future discoveries are made. Campbell (1988) likened education through self-awareness to teaching an athlete in the sense that "A good coach doesn't tell a runner exactly how to hold his arms or anything like that. He watches him run, then helps him to correct his own natural mode" (p. 143). According to Miller (2001), it is only through action followed by nonjudgmental observation that true biases and predispositions emerge and the process of transformation begins.

\section{An Emergence Model for Teaching Counseling Theories}

Recognizing limitations of the modernist approach, constructivist have offered techniques for adapting modernist principles to facilitate critical self-reflection and theoretical fit among counselor education students. However, rather than continually adapting the modernist approach, it may be useful to consider an alternative model, one that not only recognizes students' internal wisdom, but allows it to fully emerge in ways that permit both students and instructors to embrace students' predispositions as the founda- tion for learning. Rather than initiating students' learning of theories through reading, lecture, or small-group discussions, the pedagogical principles of radical constructivism and transformative learning provide the rationale and basic structure for designing a pedagogy that introduces students to theoretically based interventions by teaching them to observe and reflect upon their own real-world practice.

Certainly, beginning learning of theory through observations of one's own practice should not equate to sending students into their first coun seling experiences without preparation; rather, it is a philosophical shift in counselor educators' definition of in counselor educators' definition of the foundational learning needed before students begin practice. Consistent with many counseling programs, the Emergence Model stresses that students learn basic listening and attending skills, such as how to ask open-ended questions, paraphrase, and demonstrate empathy (see Hackney \& Cormier, 2001) before they begin their supervised practice. In addition, cormier, 2001) cators have an ethical obligation pretion, counselor eduthat challenge their assumptions age them to explore peronal in culture and encourthera them from being However, to others before they begin practice.

However, rather than beginning their practice with an espoused theory from which to operate, the Emergence Model introduces students to interventions through nonjudgmental observation of themselves and their own practice. Armed with basic listening and attending skills, and with the support of their instructor and peers, students are encouraged to fupport of their instructor and peers, students are encouraged to formulate interventions with clients based on their instincts and preexisting knowledge. The role of the counselor educator is not to judge the interventions but, rather, to assist students in identifying their natural helping instincts and to push them to consider the strengths and limitations of these interventions.

Instructors who use the Emergence Model for teaching theories take a role similar to that of a constructivist supervisor. In fact, Neufeldt's (1999) Constructivist Model of Supervision provides excellent examples thow the instructor and peers can present questions to students that focus on how they decided upon a particular intervention what they imagined the client would do in Constructivist Model of Supervision, the goal of the Emergence Model is to move students from asking if their interventions were right to asking what they learned from the interactions. However, unlike Neufeldt's (1999) model, the emergence approach allows students begin their exploration of interventions without the blind students to nally imposed points of view or the burdhout the blinders of exter espoused theory.

It is foreseeable that counselor educators who are accustomed to the modernist philosophy that theory must precede practice have concerns about introducing students to intecede practice will real-world experiences. For example through philosophy is the fear that the modernist ents without a theory with trainees will make mistakes with cliand formulate interventions. Obviou client issues 
interventions based on natural instincts, there is a risk that some of their interventions may not be appropriate counseling behavior. However, the fact that research indicates students often revert to their natural instincts once they begin their professional practice (Argryis \& Schön, 1974; Skovholt \& Ronnestad, 1992) reinforces the need to identify and understand these frames of reference before students begin their first professional counseling experiences. Rather stude than make these mistakes in their profir natural helping behavior gence Model allows s under the supervision of an experienced counselor who can help students become aware of these predisposed notions and encourage them to consider alternative intervention strategies.

A second fear regarding having students begin their practice without a theoretical orientation with which to conceptualize client issues is that students will become overwhelmed by anxiety. Indeed, both modernist and constructivist educators agree that anxiety is inherent when students begin their learning. However unlike the modernist approach, in which anxiety stems from the fear of "doing it wrong," students who learn interventions by observing their own practice experience a different type of anxietyone that challenges their predisposed notions of change and growth and forces them to consider the limitations of these ingrained frame of reference. Moreover, whereas the modernist approach is designed to reduce student anxiety, the emergence approach embraces student anxiety as a basis for stimulating the dissonance required to facilitate predispositions and self-reflection. Additionally, begin ning practice without a theoretical orientation forces students to attempt seemingly novel approaches. This may facilitate counselor risk taking, which Kottler (1993) identified as one of the most important characteristics of successful counselors.

A third fear of introducing students to interventions through practice is that students will ignore counseling research and theoretical foundations. Indeed, there is evidence that many practitio(Falvey, 1989). Howard, 1986) or value counseling theories (Falvey, 1989). However, Schön (1995) believed that this rift between theory and practice was the result of modernist pedagogy that does not value critica self-reflection or theoretical fit. Although the Emergence Model emphasizes learning interventions through practice, it is not an atheoretical model; it is merely a logical shift in the order in which theory is introduced. Instead of using theory to guide students initial practice, instructors using the Emergence Model introduce theoretical concepts to students after they have begun to observe and understand their instinctual interventions with clients. In addition to helping students observe their behaviors, the instructor encourages students to compare their interventions to existing theories to assist students in understanding themselves better and improving their natural modes of helping.

Introducing students to theory after they have begun practice has been supported by Hart (1990) who, in describing her notion of transformative learning, asserted that while personal experiences should be the point of departure for meaningful learning. individual experiences cannot be fully understood and broadened without relating these experiences to established, researched theoretical perspectives. Kottler (1993) also believed that combining intuition with established theories facilitates counseling "that is both creative and cautious, radical and responsible" (p. 246). Therefore, although counselor educators using the Emergence Model would not begin by introducing students to established theories, theory plays a critical role in assisting students in understanding their assessments and interventions and in encouraging them to be open regarding new possibilities for their practices.

As with other constructivist approaches to counselor education. the success of the emergence approach hinges upon the instructor's ability to provide an environment that is safe and that encourages students to take risks. Instructors should frequently emphasize that mistakes are integral to facilitating self-awareness and reflection. Moreover, students need to feel free to critically respond to each other in ways that both support and challenge peers to examine new ways of understanding their practice. In addition, counselor educators using the Emergence Model should continually encourage self-reflection through their direct supervision of students as well through additional assignments such as reflective journaling and case analyses. Finally, the success of the Emergence Model hinges on the instructor's ability to help students link their practice to theory. Rather than writing an essay at the end describing their theory of choice, the Emergence Model forces students to not only describe what they think they do, but to actually analyze, deconstruct, and demonstrate their theoretical perspective in action.

\section{Conclusion}

Beginning the instruction of theory by allowing students to observe and understand their natural helping instincts is a drastic diver gence from the modernist approach. However, alternative approaches such as the Emergence Model, provide a pivotal beginning toward reexamining counselor education pedagogy. Although the Emergence Model provides potential for facilitating critical self-reflection and theoretical fit, the viability of this approach needs to be supported by research before firm conclusions can be drawn. Results of this review indicate that relatively little attention has been given to understanding counseling education's pedagogical practices. To continue to ensure that counselor trainees receive the best possible training. more research is needed to understand the effects of various pedagogical approaches on different learning outcomes.

\section{References}

Argyris, C., \& Schön, D. A. (1974). Theory in practice: Increasing professional effectiveness. San Francisco: Jossey-Bass.

( Making the pieces fit. Counselor Education and Supervision, 31, 232-237. 
Bruner, J. (1966). Towards a theory of instruction. Cambridge, MA: Harvard Press. Burck, H., Jacobs, E., Sauber, R., Stone, W., \& Thomson, W. (1973). Teaching a course in counseling theories and practice: Descrip

thon. Counselor Education and Superh. New York: Doubleday.

Campbell, J. (2001). Thou art that. Novato, CA: Joseph Campbell Foundation

Conway, J. B. (1988). Differences among clinical psychologists: Scientists,

practitioners, and scientist-practitioners. Professional Psychology: Research and Practice, 19, 642-655.

Corey, G. (2001). Theory and practice of counseling and psychotherapy (6th ed.). Belmont, CA: Wadsworth.

Council for Accreditation of Counseling and Related Educational Programs. (2001). CACREP accreditation manual. Alexandria, VA: Author

Cranton. P. (1994). Understanding and promoting transformative learning. San Francisco: Jossey-Bass

Duckworth. E. (1986). Teaching as research. Harvard Educational Review, 56 , $481-495$.

Falvey, E. (1989). Passion and professionalism: Critical rapprochement for mental health research. Journal of Mental Health Counseling. 11, 86-95.

Fong, M. L. (1998). Considerations of a counseling pedagogy. Counselor Edu-

Garfield, S. L., \& Bergin, A. E. (1994). Introduction and historical overview In A. E. Bergin \& S. L. Garfield (Eds.), Handbook of psychotherapy and behavior change (pp. 3-18). New York: Wiley.

(1998). A developmental rationale for curricuoder and teaching styles in counselor education programs. Counselor Education and Supervision, 38, 89-105.

(1995). A dialectical constructivist ap-

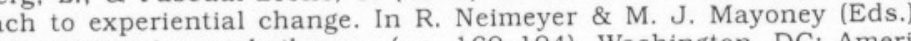
Washington, DC: American Psychological Association.

Follins, B. (2002, October). The role of theory in coliuselor preparation. Paper presented at the meeting of the Association for Counselor Education and Supervision, Park City, UT.

Hackney. H. \& Cormier, L. S. (2001). The professional counselor: A process guide to helping. Needham Heights, MA: Allyn \& Bacon.

(1996). Theory and experience: Teaching dialectical thinking in counselor education. Counselor Education and Supervision, 36, 14-24.

Hart, M. U. (1990), Liberation through consciousness raising. In J. Mezirow (Ed.), Fostering critical reflection in adulthood (pp. 47-73). San Francisco: Jossey-Bass.

Hayes, R. L., \& Paisley, P. O. (2002). Transforming school counselor preparation programs. Theory Into Practice, 41, 169-176.

House, R. M., \& Sears, S. J. (2002). Preparing school counselors to be leaders and advocates: A critical need in the new millennium. Theory Into Practice, 41, 154-162.

Howard, G. S. (1986). Dare we develop a human science? Notre Dame, IN: Academic Publications. Kottler, J. A. (1993). On being a therapist. San Francisco: Jossey-Bass.
Kottler, J. A. (2002). Theories in counseling and therapy: An experiential ap-

Kottler, J., \& Young, M. (2002, October). Teaching theories of the past using strategies of the future. Paper presented at the meeting of the Association

Krishnamunti, J. (1953). Education and the significance of life. New York: Harper

\& Row.
Lovell, C., \& McAuliffe, G. J. (1997). Principles of constructivist training and education. In T. L. Sexton \& B. L. Griffin (Eds.), Constructivist thinking in counseling practice, research, and training (pp. 211-228). New York: Teachers College Press.
Mahoney, M. J. (1995). Cognitive and constructive psychotherapies, New York: Springer.

McAuliffe, G., \& Eriksen, K. (2000). Preparing counselors and therapists: Creating constructivist and developmental programs. Virginia Beach, VA: Donning. preory to practice. In P. Cranton San Francisco: Jossey-Bass.

Miller, J. (2001). Learning from a spiritual perspective. In E. O'Sullivan, A. Morelli, \& M. A. O'Connor (Eds.), Expanding the boundaries of transforma. tive learning (pp. 95-102). New York: Palgrave.

Nelson, M. L., \& Neufeldt, S. A. (1998). The pedagogy of counseling: A critical examination. Counselor Education and Supervision, 38, 70-88.

Neufeldt, S. A. (1997). A social constructivist approach to counseling supervision. In T. L. Sexton \& B. L. Griffin (Eds.), Constructivist thinking in counseling practice, research, and training (pp. 191-210). New York: Teachers College Press.

Neufeldt, S. A. (1999). Supervision strategies for the first practicum. Alexandria, VA: American Counseling Association.

Poznanski, J. J., \& McLennan, J. (1995). Conceptualizing and measuring counselors theoretical orientation. Journal of Counseling Psychology, 42. $411-422$

Sammons, M. T., \& Gravitz, M. E. (1990). Theoretical orientations of professional psychologists and their former professors. Professional Psychology: Research and Practice, 21, $131-134$.

Schön, D. A. (1983). The reflective practitioner: How professionals think in ac tion. New York: Basic Books.

Schön, D. A. (1995, November/December). The new scholarship. Change, 27. $27-34$.

Sexton, T. L., \& Griffin, B. L. (1997). Constructivist thinking in counseling practice, research, and training. New York: Teachers College Press.

kkovholt, T. M., \& Ronnestad, M. H. (1992). Themes in therapist and counse lor development. Journal of Counseling \& Development, 70. 505-515.

mith, D. A. (1999). The end of theoretical orientations? Applied and Preventive Psychology, 8, 269-280.

pruill, D. A., \& Benshoff, J. M. (2000). Helping beginning counselors develop a personal theory of counseling. Counselor Education and Supervitone, G. L., \& Yan,

\& Yan, S. Y. (1997). Differences between psychologists workin in counseling centers and independent practice. Journal of College Student Psychotherapy. 12, 41-63.

von Glasersfeld, E. (1984). An introduction to radical constructivism. In P. Watzlawick (Ed.), The invented reality (pp. 17-41). New York: Norton.

von Glasersfeld, E. (2000). Cognition, construction of knowledge, and teaching. University of Massachusetts. Amherst Scientific Reasoning Research Institute, Retrieved July 15, 2003, from http://www.umass.edu/srri/ vonGlasersfeld/onlinePapers/html/117.html

Ward, C. C.. \& House, R. M. (1998). Counseling supervision: A reflective model. Counselor Education and Supervision, 38, 23-33.

White, M., \& Epston, D. (1990). Narrative means to therapeutic ends. New York: Norton.

Winslade, J., Monk, G., \& Drewery, W. (1997). Sharpening the critical edge: A social constructionist approach in counselor education. In T. L. Sexton \& B. L. Griffin (Eds.), Constructivist thinking in counseling practice, research. and training (pp. 228-248). New York: Teachers College Press. 